\title{
Physicochemical, microbiological and sensorial characteristics of flour and prepared cookies from the reject cashew (Anacardium occidentale L.) neglected
}

Características físico-químicas, microbiológicas e sensoriais da farinha e cookies preparados a partir do rejeito negligenciado do caju (Anacardium occidentale L.)

Características físico-químicas, microbiológicas y sensoriales de harina y galletas preparadas a partir de residuos de castañas de cajú (Anacardium occidentale L.)

Leonardo Bruno Aragão de Araújo ORCID: https://orcid.org/0000-0001-8162-4250 Potiguar University, Brazil

E-mail: leobiubao@yahoo.com.br Jefferson Romáryo Duarte da Luz ORCID: https://orcid.org/0000-0002-8249-7617 Potiguar University, Brazil

E-mail: jefferson_romaryo@hotmail.com

Débora Batista

ORCID: https://orcid.org/0000-0003-2201-3104 Potiguar University, Brazil

E-mail: deborabioquimica@gmail.com

Andréia da Cunha Bezerra ORCID: https://orcid.org/0000-0003-1850-2191 Potiguar University, Brazil E-mail: andreiacunhanutricionista @gmail.com

Heryka Myrna Maia Ramalho ORCID: https://orcid.org/0000-0001-5874-3411 Potiguar University, Brazil E-mail: herykamyrna@gmail.com

Ana Katarina Menezes da Cruz Soares ORCID: https://orcid.org/0000-0001-9886-0604 Potiguar University, Brazil E-mail: anakatarina1@uol.com.br

Maria Aparecida Medeiros Maciel ORCID: https://orcid.org/0000-0002-4799-0609 Potiguar University, Brazil E-mail:mammaciel@hotmail.com

\begin{abstract}
Nowadays, one of the main objectives of biotechnological development of new products is linked to processes and methods improvement. In this sense, the aim of this work is to promote the sustainable development of the residue obtained from the cashew's organic reject material aiming at to produce a target flour to be applied as a functional food. In fact, the nutritional composition of the cashew flour showed an important food profile related to fibers and carbohydrates. In relation to the prepared food as a simple possibility, cookies were produced, and its sensorial characteristics were carried out in individual booths, with 100 non trained evaluators. The results showed that the cookies demonstrated a satisfactory acceptance profile in several analyzed attributes. Concerning to the microbiological analysis, nonsignificant presence of microorganisms was detected. So, the processed cashew flour showed to be nutritionally acceptable and together with a good sensorial acceptance, can be considered as a suitable biomass to produce a large amount of bakery products.
\end{abstract}

Keywords: Anacardium occidentale L.; Cashew flour; Sustainable development; Functional food.

\section{Resumo}

Atualmente, um dos principais objetivos do desenvolvimento biotecnológico de novos produtos está ligado ao aprimoramento de processos e métodos. Nesse sentido, o objetivo deste trabalho é promover o desenvolvimento sustentável do resíduo obtido do rejeito orgânico do caju com o objetivo de produzir uma farinha alvo para ser aplicada como alimento funcional. De fato, a composição nutricional da farinha de caju apresentou um importante perfil alimentar relacionado às fibras e carboidratos. Em relação ao alimento preparado como possibilidade simples, foram produzidos cookies, e suas características sensoriais foram realizadas em cabines individuais, com 100 
avaliadores não treinados. Os resultados mostraram que os cookies demonstraram um perfil de aceitação satisfatório nos diversos atributos analisados. Quanto à análise microbiológica, não foi detectada presença significativa de microrganismos. Assim, a farinha de caju processada mostrou-se nutricionalmente aceitável e juntamente com uma boa aceitação sensorial, pode ser considerada uma biomassa adequada para a produção de grande quantidade de produtos de panificação.

Palavras-chave: Anacardium occidentale L.; Farinha de caju; Desenvolvimento sustentável; Alimento funcional.

\section{Resumen}

Actualmente, uno de los principales objetivos del desarrollo biotecnológico de nuevos productos está vinculado al mejoramiento de los procesos y métodos. En este sentido, el objetivo de este trabajo es promover el desarrollo sustentable del residuo obtenido del material orgánico descartado de la castaña de cajú, con el fin de producir una harina para ser utilizada como alimento funcional. De hecho, la composición nutricional de la harina de cajú mostró un importante perfil dietético relacionado con las fibras y los carbohidratos. En relación al alimento preparado como una alternativa simple, se elaboraron galletas y sus características sensoriales fueron testeadas en stands individuales, con 100 evaluadores no capacitados. Los resultados mostraron que las galletas tuvieron un perfil de aceptación satisfactorio en las distintas características analizadas. En cuanto al análisis microbiológico, no se detectó presencia significativa de microorganismos. Así, la harina de cajú procesada demostró ser apta nutricionalmente y aceptable sensorialmente, por lo cual puede considerarse un recurso adecuado para la producción de una gran cantidad de productos de panadería.

Palabras clave: Anacardium occidentale L.; Harina de caju; Desarrollo sustentable; Alimento funcional.

\section{Introduction}

Among the years from 2007 to 2017, Brazil was considered one of the largest fruit producers in the world, accompanied by China, India and the United States (Fidelis et al., 2019). The Northeast region features large importance in the cultivation of most species of tropical fruits, which are widely spread for its nutritional and sensorial characteristics as well as in the production of many foods such as candies and juices (Lousada Junior et al., 2006). Brazil boasts many underexploited native and exotic fruit species of potential interest to the agro-industry and a possible future source of income for the local population (Silva et al., 2014).

The cashew tree (Anacardium occidentale LINN) is considered one of the most important fruitful tree, because of its food commercial products being a rich source of fibers, minerals and vitamins, also presents a good percentage of nondigestible carbohydrates, and also bioactive compounds, such as flavonoids, being the only species of the genus Anacardium to be cultivated on a commercial scale in the world (Marín et al., 2002; Rico et al., 2016; Salehi et al., 2019; Santos et al., 2007; Schweiggert et al., 2016; Oliveira et al., 2020).

Over the years, agribusinesses have invested in the increase of processing fruits capacity, promoting a high production of residues, the most abundant being represented by products of fruits and vegetables, with a percentage in the range $40 \%$ to $50 \%$ of the total residues generated (Dilucia et al., 2020). Fruit and vegetable waste are discarded in the form of leftovers, such as seeds, pulp, peel or bagasse, representing 10\% to 35\% of gross mass (Sousa et al., 2011; Mirabella et al., 2014). In a global context, food waste and residues represent a loss of approximately USD 310 billion in developing countries, such as Brazil (Nogueira et al., 2020).

Nowadays, alternatives to reuse food residues aiming at reduction of environment impact, dry food residues to the achievement of flour as an ingredient rich in fibers to incorporate various foods, substituting full or partially wheat flour represent a friendly technological improvement in the food industry (Ayala-Zavala et al., 2010; Matias et al., 2005).

Around the world, baking products such as breads, cakes and cookies are largely consumed having wheat flour as basic ingredient. Many researches have been realized with the objective to substitute the wheat in the handling of these products in view of, mainly, the growing economic and commercial restrictions, new consuming tendencies, specific eating habits and the need of diversification and/or innovation of these products (Pinto et al., 2011). 
In general, food waste has a huge potential to be recycled because it's a natural source of nutrients, such as carbohydrates; pectin and fibers, as well as, valuable bioactive molecules such as phenolic acids, carotenoids, tocopherols and flavonoids, representing a class of compounds that are very beneficial for human nutrition due to their therapeutic properties (Biazotto et al., 2019; Dilucia et al., 2020). High-fiber foods are designated as functional, being essential to maintain health and reduce the risks of several diseases, like sanguine cholesterol decrease, protection against cancer, increase of intestinal transit, intervention on lipids and carbohydrates metabolism and on physiology of gastrointestinal tract (Müller et al., 2018; Ribeiro \& Finzer, 2010; Soares et al., 2000; Jalali et al., 2020).

According to Schieber et al. (2001), the quantity of residues generated by the processing of fruits can achieve many tons, assembling value to those products is of economic and environmental interest, and for that, scientific and technological studies are needed to enable its use. Therefore, the objective of this study was to perform a research aiming at the best utilization of the bagasse of neglected cashew, to obtain a flour, that was characterized and used in the production of cookies, which were physicochemical characterized, related to its nutritional and sensorial capacity, besides being safe in relation to possible microbiological contaminants.

\section{Material and Methods}

The present study is characterized as original research which was developed as laboratory and qualitative type. Since qualitative methods are described as being of paramount importance the interpretation and opinion of the researchers on the data and as well as in the discussed results, make the applied approach indispensable. The methodological support for this research type is in agreement with previously report (Pereira et al., 2018).

\subsection{Cashew sample}

The neglected cashew bagasse residue was provided by the fruit pulp company, "Pura Polpa", situated in Parnamirim, Rio Grande do Norte. The material was obtained frozen, transported in a thermal box, to the Potiguar University (UnP) Biotechnology Laboratory, where was subject to drying in a conservatory with air circulation (Marconi MA035) in aluminum tray, with $300 \mathrm{~g}$ of sample and one centimeter of thickness, at $60^{\circ} \mathrm{C}$ for 8 to 12 hours, until achieves total humidity bellow $10 \%$. Then, the residue was crushed (processor ARNO®) and passed through a strainer of 70 mesh to obtain a homogeneous cashew flour (named CF) that was packed in a plastic and sterile container, protected from light. The storage at room temperature $\left(24^{\circ} \mathrm{C}\right)$ occurred for about 48 hours, until its utilization.

\subsection{Preparation of cookies with the cashew flour biomass}

For the preparation of cookies, it was used the method according to the American Association of Cereal Chemists (AACC) "sugar-snapcookie" method number 10-50D with some modifications. The standard product was made with the traditional wheat flour, while the tests contained $10 \mathrm{~g}$ and $15 \mathrm{~g} / 100 \mathrm{~g}$ of the cashew flour biomass (CF) in substitution to the content of wheat flour. The ingredients were mixed to obtain a gradual reduction of thickness. The batter was molded in cookies and baked, in a domestic oven, at $150^{\circ} \mathrm{C}$ for 15 to 20 minutes. Once baked, the cookies were left to cool for 30 minutes and stored in a polypropylene container with hermetic cover. The process was realized three times. Table 1 shows the composition of the biscuits produced by adding different percentages of CF biomass. 
Table 1. Cookies composition with different percentages of cashew bagasse flour.

\begin{tabular}{cccc}
\hline \multirow{2}{*}{ Ingredients (g/100g) } & \multicolumn{3}{c}{ Levels of substitutions } \\
\cline { 2 - 4 } & Control & $\mathbf{1 0 g}$ CF/100g & $\mathbf{1 5 g}$ CF/100g \\
\hline Wheat flour $(\mathrm{g})$ & 150.00 & 148.50 & 140.25 \\
Sugar (g) & 100.00 & 100.00 & 100.00 \\
Hydrogenated vegetal fat (g) & 60.00 & 60.00 & 60.00 \\
Milk (mL) & 20.00 & 20.00 & 20.00 \\
Vanilla essence (mL) & 5.00 & 5.00 & 5.00 \\
Salt (g) & 0.02 & 0.02 & 0.02 \\
Yeast (g) & 1.0 & 1.0 & 1.0 \\
Cashew flour (g) & - & 16.5 & 24.75 \\
\hline
\end{tabular}

Source: Authors.

\subsection{Physicochemical characterization}

The flour obtained from cashew bagasse and the elaborated cookies with percentage were characterized according its proximate composition. The moisture content was determined by drying in conservatory at $105^{\circ} \mathrm{C}$ (gravimetric method), the mineral residue (ashes) by incineration at $550^{\circ} \mathrm{C}$ (Lutz, 1985). The total lipids content was determined through the method of direct extraction with petroleum ether in Soxhlet, the protein by organic nitrogen content (\%), according to Kjeldahl's method, using factor 6.25 for the nitrogen conservation in proteins according to AOAC (Horwitz, 1980). The quantification of soluble and insoluble fiber was determined by the Enzymatic-Gravimetric method (Ascar, 1985). The carbohydrates content was determined by the calculation of the difference between 100 grams of flour and the total amount of percentage values found for proteins, lipids, ashes, fiber and humidity. The calorific value for the flour was obtained using factors of Atwater, 32 multiplying the carbohydrates and protein values for $4 \mathrm{kcal} / \mathrm{g}$ and $9 \mathrm{kcal} / \mathrm{g}$ for lipids.

All the physicochemical analysis was performed in triplicate. The total titratable acidity was verified though the titration $0.1 \mathrm{M} \mathrm{NaOH}$ and the $\mathrm{PH}$ was determined through a PH measurer (Quimis ${ }$ ). The cookies obtained from the cashew flour were also characterized, and the data summarized in Table 2.

\subsection{Microbiological analysis}

Analysis of coliforms were made at $35^{\circ} \mathrm{C}$, coliforms at $45^{\circ} \mathrm{C}$, Salmonela sp, Staphylococcus aureus, filamentous fungi and yeast, aerobic mesophilic and Bacillus cereus count, according to American Public Health Association methodology.

To carry out the microbiological analysis five repetitions of the cashew bagasse flour samples. Were used 25 grams of the sample were weighted for each analysis and put in a saline solution in peptone water $(0,1 \%)$, sterile; after, dilutions were made for inoculation of the different culture used in the experiment.

\subsection{Cookie's sensorial test}

Sensory analysis of cookies was carried out in individual booths, with 100 non trained evaluators. Test for evaluation of attributes color, appearance, aroma, flavor, texture and overall acceptance were performed using a 9-point hedonic scale: 9 (I liked it very much); 8 (I enjoyed it); 7 (I liked it moderately); 6 (It was OK); 5 (I didn't like it/Neither did I dislike it); 4 (I didn't like it, but it wasn't too bad); 3 (I didn't like it moderately); 2 (I really didn't like it); and 1 (I hated it), as well as purchase intent and preference for ordering among samples (Meilgaard et al., 2016), using sensory record. 
The tasters described how much they liked or disliked the attributes: overall impression, aroma, texture and flavor (ABNT, NBR 14140, 1998; Dutcosky, 2011). The panelist previously received the terms of Informed Consent and Assent approved by the Ethics in Research Committee (COEP), UNP under CAAE n ${ }^{\circ}$ 35050614.4.0000.5296.

To perform the sensory evaluation, the cookies of each sample were offered to each tester in identified white disposable cups. Water at room temperature and crackers were offered to mitigate the influence of one sample on another.

\subsection{Statistic analysis}

All extraction assays were carried out in triplicate and duplicate of each extract was analyzed. Results were expressed as means \pm standard derivation (SD). One-way analysis of variance (ANOVA) was carried out by GraphPad Prism 5 software. The comparison of means was performed by Tukey test. Statistical differences were significant $(\mathrm{P} \leq 0.05)$.

\section{Results and Discussion}

The obtained cashew bagasse flour (CF) was subject to physicochemical analysis for the characterization of raw material. The analysis showed an important food profile related to fibers and carbohydrates, as can be observed on Table 2.

Table 2. Physicochemical analysis of the cashew bagasse flour and its cookies products.

\begin{tabular}{|c|c|c|c|c|}
\hline \multirow{2}{*}{$\begin{array}{c}\text { Studied Parameters } \\
\%\end{array}$} & \multirow{2}{*}{ CF } & \multicolumn{3}{|c|}{ Cashew bagasse flour cookies } \\
\hline & & Control & CF-10\% & CF-15\% \\
\hline Moisture (\%) & $5.2 \pm 0.02^{\mathrm{c}}$ & $7.33 \pm 0.001^{b}$ & $9.9 \pm 0,004^{\mathrm{a}}$ & $9.1 \pm 0,001^{\mathrm{a}}$ \\
\hline Ashes (\%) & $2.5 \pm 0.001^{\mathrm{a}}$ & $1.2 \pm 0.001^{\mathrm{c}}$ & $1.37 \pm 0.001^{\mathrm{c}}$ & $1.58 \pm 0.02^{b}$ \\
\hline Fibers $(\%)$ & $15.8 \pm 0.03^{\mathrm{b}}$ & $5.7 \pm 0.018^{\mathrm{d}}$ & $9.39 \pm 0.06^{\mathrm{c}}$ & $22.6 \pm 0.07^{\mathrm{a}}$ \\
\hline Protein $(\%)$ & $5.2 \pm 0.012^{\mathrm{b}}$ & $10.1 \pm 0.007^{\mathrm{a}}$ & $10.4 \pm 0.013^{\mathrm{a}}$ & $10.6 \pm 0.05^{\mathrm{a}}$ \\
\hline Lipids (\%) & $4.3 \pm 0.10^{\mathrm{b}}$ & $4.07 \pm 0.13^{\mathrm{c}}$ & $6.27 \pm 0.003^{\mathrm{a}}$ & $6.53 \pm 0.01^{\mathrm{a}}$ \\
\hline Carbohydrates (\%) & $67.0 \pm 0.2^{b}$ & $71.56 \pm 0.18^{\mathrm{a}}$ & $61.67 \pm 0.02^{\mathrm{b}}$ & $48.83 \pm 0.6^{c}$ \\
\hline $\mathrm{pH}$ & $3.4 \pm 0.03^{\mathrm{b}}$ & $6.43 \pm 0.02^{\mathrm{a}}$ & $6.22 \pm 0.01^{\mathrm{a}}$ & $6.14 \pm 0.01^{\mathrm{a}}$ \\
\hline Acidity & $3.45 \pm 0.01^{\mathrm{d}}$ & $6.8 \pm 0.14^{\mathrm{c}}$ & $8.6 \pm 0.03^{\mathrm{b}}$ & $10.6 \pm 0.03^{\mathrm{a}}$ \\
\hline
\end{tabular}

Values are means of three replicates. *Equal letters in the same line do not differ significantly $(\mathrm{p}<0.01$ and $\mathrm{p}<0.05)$. Source: Authors.

\subsection{Nutritional composition ( $\mathrm{g} \%$ ) of the cashew bagasse flour and its cookies products.}

The moisture level found on the CF biomass $(5,2 \%)$ is reduced by half when compared to the macambira crumb flour $(10,6 \%)$, being more elevated than found on the green banana flour (3,3\%) (Farias et al., 2011). Although, it's significantly less than that found on cashew flour obtained from the fruit in natura pressed $(14,73 \%)$, as well as on passion fruit flour $(6,04 \%)$ (Souza et al., 2010).

The CF biomass presented value in satisfactorily inside of moisture content for flours and bran specified by the Brazilian national health surveillance agency (so called ANVISA) which must be between 5 and 15\% (Brasil, 2005). Low moisture values are important, because flours with humidity over 14\% tend to form grumes, which can damage the production of pastas by continuous process (Fernandes et al., 2008). Besides that, in flours with humidity excess, there is the possibility of development of microorganisms, such as fungi and the decrease of flour's stability, decreasing so it's life on the shelf (Sgarbieri, 1987).

The moisture contents of the cookie's formulations elaborated with CF biomass differed statistically $(\mathrm{p}<0,05)$ from each other, being larger in relation to the found for the cashew flour (Table 2). Showing that the temperature $\left(180-220^{\circ} \mathrm{C}\right)$ used on the cookie's baking, didn't cause humidity loss.

The ashes content showed that $\mathrm{CF}$ presents inferior value than the previously results found on passion fruit flour $(6,86 \%)$ and grape flour $(38,03 \%)$. Although, a value significantly near to the banana flour $(2,62 \%)$ is bigger than the one 
found on macambira's bracts flour $(1,87 \%)$ and the jabuticaba peel $(0,5 \%)$, therefore, can be considered as alternative source of minerals (Boari et al., 2008; Farias et al., 2011; Fasolin et al., 2007).

For ashes content not significantly difference was observed for the cookies supplemented with cashew bagasse flour, and that the same increased progressively with the addition of CF biomass content, and as well when we compare to control.

The biomass CF has $15,8 \%$ of fibers, whose value is of great worth for consuming, due to its benefits, as well as intestinal, for helping on digestion, as sanguine, for decreasing the cholesterol concentration on circulation (Soares et al., 2000). This value was a little lower than the one found in banana and bocaiúva flour (Kooper et al., 2009; Menezes et al., 2011). Although, it's much higher than the one found in green banana flour (1,01\%) and substantial when compared to flours elaborated with residues from Brazilian fruits such as acerola and umbu (Abud \& Narain, 2009). In addition, a higher value than those found in cookies made from seriguela (Spondias purpurea L.) that were reported with $12.83 \%$ of dietary fiber (Albuquerque et al., 2016).

The quantity of fibers was larger in the experimental formulations, when compared to the control ones (Table 2). A food with a content of about $3 \mathrm{~g} .100 \mathrm{~mL}-1$ can be considered as a good source of dietary fiber, according to the technical regulation, relative to the complementary nutritional information, with double of this content, can be treated as aliment with high dietary fiber content (Brasil, 1998). The addition of dietary fiber in food grants many kinds of benefits. Its nutritional value motivates consumers to increase the fibers consumption, which is advised by professionals. They can also value agricultural products and by-products to use as ingredients (Deamici et al., 2018).

The value obtained for the CF biomass proteins $(5,2 \%)$ is higher than the one found in banana flour $(3,6 \%)$ (Musa acuminata, var. Nanicão) resembling the one found in banana flour (4,54\%) (Musa AAA type, as well as 'Cavendish anã ' (Menezes et al., 2011; Fasolin et al., 2007). This result being higher than the described for acerola, umbu and passion fruit (Abud \& Narain, 2009), and lower than the ones found for guava and cashew flour from the pulp (Uchoa et al., 2009). Also, the protein value described by Salgado et al. (2008) for avocados.

According to Table 2 the proteins value increases with the addition of CF, what wasn't expected, once the quantity of wheat flour was reduced in the formulation, being this one richer in proteins than the cashew flour.

The quantity of total lipids on CF biomass is significant, when compared to the detected in the macambira crumb flour $(1,75 \%)$ (Farias et al., 2011). However, shows inferior value of that found in the guava flour (14,0 5\%), orange (6\%), avocado (37,5\%) (Uchoa et al., 2009; Chaves et al., 2013). These data are important for the reserve, mainly in the adipose tissue, providing energy, but not contributing to the osmotic pressure inside the cell. The total fat content of the cookies standard formulation of cookies was significantly lower than the experimental formulations.

The CF's glicidic fraction (67\%) shows results near to the value found in the macambira crumb flour (66,31\%) (Farias et al., 2011), but it's four times higher than the detected in avocado flour (16,49\%) and guava flour $(8,69 \%)$. However, it's lower than the value found on mango flour (84,11\%) (Uchoa et al., 2009; Chaves et al., 2013).

In Table 2 it is possible to observe that there is a significant difference between the standard cookie and the tests (CF$10 \%$ and $\mathrm{CF}-15 \%)$ related to the sugar value. In the other hand, no significant difference was observed between the test cookies and the cashew bagasse flour biomass (CF), in comparison to the approximate composition of another cookie produced from the cashew juice bagasse, in the region of Goiás/Brazil, which showed lower protein contents $(9.40 \pm 0,0)$ and higher concentrations of lipids $(7,40 \pm 0,16)$ and carbohydrates $(71,01 \pm 0,01)$ (Medeiros et al., 2020), suggesting that the region of cultivation, as well as, the processing may interfere in the chemical composition of products and as well as by others products of plant species.

The $\mathrm{pH}(3,4)$ found for $\mathrm{CF}$ is near to the described value observed for the avocado pulp flour $(3,54 \%)$ (Chaves et al., 2013). The values found for other cashew flours obtained from the fruit in natura by Alcântara et al. (2010), Uchoa et al., 
(2009) and Santos et al. (2007) are higher than the ones observed on Table 2. Comparing to the found values for cashew bagasse flour (in natura and by its drying), being observed that there is a light decrease. According to Alcântara et al. (2013), this finding can be related to the drying process, which accumulates organic acids.

Measurement of $\mathrm{pH}$ on food can be used to determine many parameters, such as: the deterioration of the food with the growing of microorganisms, enzyme activities, retention of the taste-odor of fruit products, verification of the fruits maturation state, choice of packing, and can be related to the lipids value in the flour, contributing to the increase of lifespan on the shelf (Fernandes et al., 2008).

An important parameter on the appreciation of the conservation state of a food product is the acidity. The acidity value found in the CF biomass (3,45\%) is like the one described for the avocado flour (3,54\%) (Chaves et al., 2013). However, according to Uchoa et al. (2009), the flour obtained from the pressed cashew's peduncle $(1,36 \%)$ and guava $(0,97 \%)$ presents values largely inferior to the found one. This variation shall be related to the fact that flours were obtained in a different way.

Regarding cookies, these showed higher values, remembering that the acidity of a food can be originated from the natural compounds of the product, can be formed by the fermentation or by the kind of process that the food passed through, and, yet, can be the result of the food deterioration.

\subsection{Sensorial test}

The cookies made with the addition of different values of CF biomass are presented in Figure 1. The average grades for the analyzed attributes according to Table 3, situated between the hedonic terms "liked very much" and "disliked moderately". The cookies with CF-10\% showed the higher hedonic classification for all sensorial attributes related to texture (7.2), statistically differing from the considered control formulation. The cookies with CF-15\% showed lower scores in almost every sensorial analyzed parameter.

The tasters reported the what they liked the most and what they disliked in relation to the cookie's global aspects. They said they liked the taste of the cookies better with $10 \%$ addition of the CF biomass. What least pleased the tasters was the taste of the cookie with CF-15\%. In every applied sensorial parameter, the assigned grades by the tasters was situated inside the acceptation zone (grades higher than 6) (Table 3).

Figure 1. Visual appearance of the cookies made with CF biomass. (a) Control sample 100g; (b) Replacement of 10\% of CF biomass/100g; (c) Replacement of $15 \%$ of CF biomass/100g.
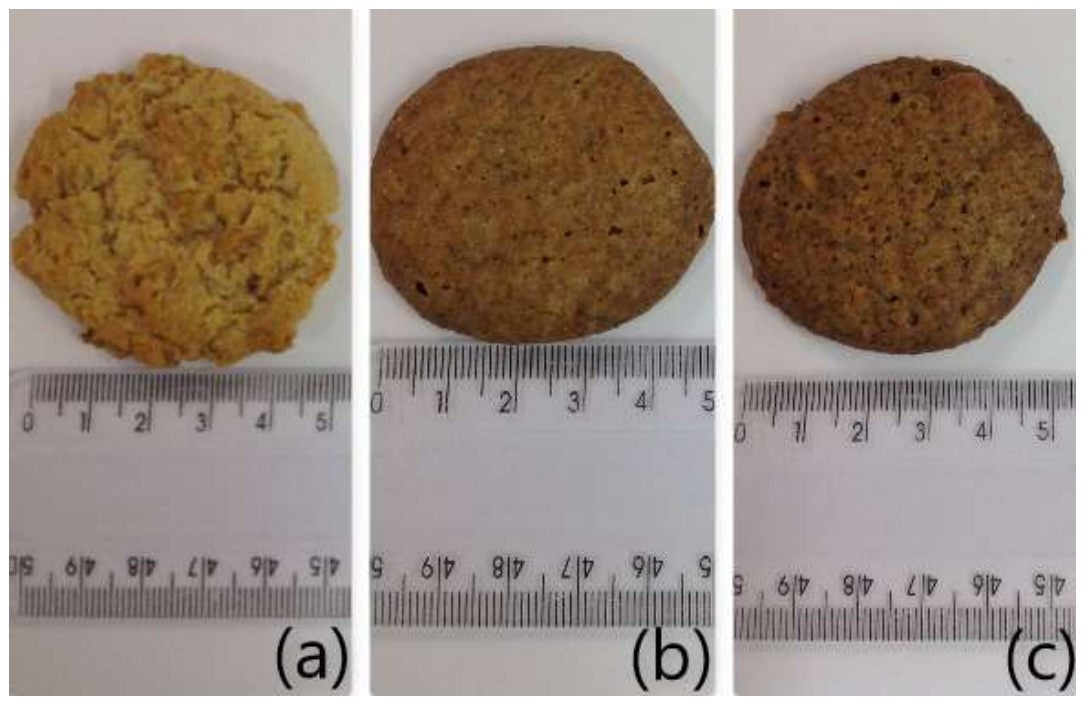

Source: Authors. 


\subsubsection{Mean sensory score of cookies supplemented with the cashew bagasse flour biomass (CF).}

The whole sensorial analysis demonstrated that cookies enriched with CF-10\% was more accepted (Table 3). Meanwhile, it was observed satisfactory acceptation in every studied parameter, for all the tested samples, not being observed significant difference $(\mathrm{p}<0.05)$ between the control sample and the samples enriched with the biomass CF. The results ensemble of the present study is according to Santucci et al., (2003), that affirmed that the flour mix of unconventional products with wheat flour improves the nutritional quality of the products, can also improve its palatability, making them more acceptable by consumers. These results are in accordance with those obtained for a cereal bar produced from the cashew bagasse, showing that the average of the hedonic values for the attributes aroma, flavor, texture and global acceptance indicate a good acceptance of the product by the tasters (Lima et al., 2021). Additionally, it is in agreement with artisanal burgers produced from cashew (Rosa et al., 2020). For the cashew cookies samples produced in this study, it was observed a decreasing value in the sensorial characteristics relative to the quantity taste by addition of CF content. However, in relation to smell, texture and flavor, the cookie containing $10 \%$ of FC overcame.

Table 3. Mean sensory score of cookies supplemented with the cashew bagasse flour biomass (CF).

\begin{tabular}{lcccc}
\hline \multirow{2}{*}{ Cookies } & \multicolumn{3}{c}{ Mean score of attributes } \\
\cline { 2 - 5 } Global aspect & Aroma & Texture & Taste \\
\hline CONTROL & $6.17^{\mathrm{b}}$ & $6.47^{\mathrm{b}}$ & $6.21^{\mathrm{b}}$ & $6.91^{\mathrm{a}}$ \\
CF-10\% & $6.8^{\mathrm{a}}$ & $7.08^{\mathrm{a}}$ & $7.2^{\mathrm{a}}$ & $6.89^{\mathrm{a}}$ \\
CF-15\% & $6.46^{\mathrm{b}}$ & $6.56^{\mathrm{b}}$ & $7.0^{\mathrm{a}}$ & $6.82^{\mathrm{a}}$ \\
\hline
\end{tabular}

${ }_{\text {abc }}$ Means along same vertical columns with same superscripts are not significantly differente at $\mathrm{p}<0.05$. Source: Authors.

\subsection{Microbiological analysis}

According to Foyet and Tchango-Tchango (1994) the present acidity in some products inhibits the proliferation of pathogenic microorganisms, can present fungi, yeast and non-pathogenic lactic bacteria. The analyzed samples were inside the patterns specified by the Brazilian sanitary legislation (ANVISA) which sets the count of absence of coliforms at $45^{\circ} \mathrm{C}$ by 50 $\mathrm{mL}$ and absence of Salmonella sp. in $25 \mathrm{~mL}$ of the product (Table 4). The finding microbiological results attended to the ANVISA resolution 12/1978 legislation, because on the microbiological count of coliforms group (at $35^{\circ} \mathrm{C}$ and at $45^{\circ} \mathrm{C}$ ) in the flour and elaborated CF-cookies, no bacteria of the coliform group of fecal origin was found. Comparatively, the best result was reported for the beet flour which presented $<3 \mathrm{NMP} \mathrm{g}^{-1}$ for microbiological analysis (Bassetto et al., 2013).

\subsubsection{Microbiological determination for the biomass $\mathrm{CF}$ and cashew bagasse flour cookies.}

Table 4 shows the microbiological determination for the biomass CF and the cashew bagasse flour cookies, in which the assayed microorganisms were Salmonella sp., Staphylococcus aureus and Bacillus cereus. In relation to the filamentous fungi group and yeast the value found was $<10 \mathrm{UFC} \cdot \mathrm{g}^{-1}$, therefore, considered inside the pattern, because, according to ANVISA - Resolution CNNPA $\mathrm{n}^{\circ} 12$ of 1978 , the maximum pattern for molds and yeast is up to $10^{3} \cdot \mathrm{g}^{-1}$. Indicating that during the production process, of the cashew bagasse flour and the cookies formulation, good manufacturing practices were used.

For the analysis of Bacillus cereus was found the value <10UFC. $\mathrm{g}^{-1}$. The maximum limit according to ANVISA Resolution $12 / 1978$ is $10^{3} \cdot \mathrm{g}^{-1}$. The Salmonella sp. didn't show any growth in the flour, just like the value found in the beet flour (Bassetto et al., 2013), complying with, so, the actual legislation, since the limit according to ANVISA - Resolution $12 / 1978$ is absence in 25 grams. The same result was extended to the CF elaborated cookies. 
Table 4. Microbiological determination for the biomass CF and cashew bagasse flour cookies.

\begin{tabular}{lcrrr}
\hline \multicolumn{1}{c}{ Microorganisms } & CF & Control & C-10\% & \multicolumn{1}{c}{ C-15\% } \\
\hline Yeast and molds $(\mathrm{UFC} / \mathrm{mL})$ & $<10$ & $<10$ & $<10$ & $<10$ \\
\hline Coliforms at $35^{\circ} \mathrm{C}(\mathrm{NMP} / 50 \mathrm{~mL})$ & Absence & Absence & Absence & Absence \\
\hline Coliforms at $45^{\circ} \mathrm{C}(\mathrm{NMP} / 50 \mathrm{~mL})$ & Absence & Absence & Absence & Absence \\
\hline Aerobic mesophilic $(\mathrm{UFC} / 50 \mathrm{~mL})$ & $<10$ & $<10$ & $<10$ & $<10$ \\
\hline Salmonella sp. & Absence & Absence & Absence & Absence \\
\hline Staphylococcus aureus & $<10$ & $<10$ & $<10$ & $<10$ \\
\hline Bacillus cereus & $<10$ & $<10$ & $<10$ & $<10$ \\
\hline
\end{tabular}

Source: Authors.

Regarding the Staphylococcus aureus analysis, the showed result is also inside the pattern $\left(<3 \mathrm{UFC} . \mathrm{g}^{-1}\right)$, ensuring the product's quality, being better than beet flour result $\left(<10^{2} \mathrm{UFC}^{-1} \mathrm{~g}^{-1}\right)$ (Bassetto et al., 2013). The limit according to ANVISA resolution 12/1978 is $0,1 \mathrm{~g}$ of absence. The mesophyll aerobic count presented an indication of $<10 \mathrm{UFC} \cdot \mathrm{g}^{-1}$. Therefore, serves ANVISA's 12/1978 resolution, since the maximum limit of standard count in plates is of $5 \times 10^{5} \cdot \mathrm{g}^{-1}$. The pH presented by the dry residue was 3.77 , therefore, acid. This condition is suitable for microorganism adaptation in the environment, although most of fungi develops better on environments with $\mathrm{pH}$ between 4.0 and 5.0 (Santos et al., 2007). These results are in agreement with other cashew bagasse products, where no microbiological contamination was found in the evaluated samples (Medeiros et al., 2020; Lima et al., 2021).

\section{Conclusion}

Concerning to this work, the physicochemical, microbiological and sensorial characteristics of the prepared flour from the reject cashew (anacardium occidentale l.) neglected material and its cookies provides important results as a functional food resource. The high fiber content associated to the presence of carbohydrates shows that this flour can be considered a complementary food, of low cost, can be used isolated or combined with other flours on the elaborations of baking products. The results also point out the feasibility to obtain cookies from cashew agroindustrial chain, and also highlight the nutritional and sensory characteristics of the waste cashew resource.

In order to add even more functional value to the prepared cashew product, it could be suggested to carry out future work aiming at to the evaluation of possible therapeutic effects, such as the antioxidant property, anti-inflammatory capacity and immunomodulatory activity of this herbal resource.

\section{Acknowledgments}

The authors are grateful for the grant support from Laureate International Universities group.

\section{References}

Abud, A. K. S., \& Narain, N. (2009). Incorporação da farinha de resíduo do processamento de polpa de fruta em biscoitos: uma alternativa de combate ao desperdício. Brazilian Food Technology, 12(4), 257-265.

Albuquerque, J. G., Duarte, A. M., Conceição, M. L., \& Aquino, J. S. (2016). Integral utilization of seriguela fruit (Spondias purpurea L.) in production of cookies. Revista Brasileira de Fruticultura, 38(3), 1-7.

Alcântara, S. R., Almeida, F. A. C., \& Silva, F. L. H. (2010). Pectinases production by solid state fermentation with cashew apple bagasse: water activity and influence of nitrogen source. Chemical Engineering Transactions, 20, 121-126.

Alcântara, S. R., Sousa, C. A. B., Almeida, F. A. C., \& Gomes, J. P. (2013). Caracterização físico-química das farinhas do pendúculo do caju e da casca de maracujá. Revista Brasileira de Produtos Agroindustriais, 15, 349-355.

Ascar, J. M. (1985). Alimentos - aspectos bromatológicos e legais. Eduni-sul. 
Associação Brasileira de Normas Técnicas NBR 14140. (1998). Alimentos e bebidas: análise sensorial e teste de análise descritiva quantitativa: ABNT.

Ayala-zavala, J. F., Rosas-domínguez, C., Vega-vega, V., \& González-Aguilar, G. A. (2010). Antioxidant enrichment and antimicrobial protection of fresh-cut fruits using their own byproducts: Looking for integral exploitation. Journal of Food Science, 75(8), 175-181.

Bassetto, R. Z., Samulak, R., Barana, A., \& Rosso, N. (2013). Produção de biscoitos com resíduos do processamento de beterraba (Beta vulgares L). Revista Verde de Agroecologia e Desenvolvimento Sustentável, 8(1), 139-145.

Biazotto, K. R., Mesquita, L. M. S., Neves, B. V., Braga, A. R. C., Tangerina, M. M. P., Vilegas, W., Mercadante, A. Z., \& Rosso, V. V. (2019). Brazilian biodiversity fruits: Discovering bioactive compounds from underexplored sources. Journal of Agricultural and Food Chemistry, 67(1), $1860-1876$.

Boari, L. A. J., Corrêa, A. D., Alves, A. P. C., Abreu, C. M. P., \& Dantas B. A. M. (2008). Caracterização do fruto jaboticaba (Myrciaria cauliflora) e de suas frações. Archives Latinoamericanos de Nutrición, 58(4), 416-421.

Chaves, M. A., Mendonça, C. B., Borges, C. D., \& Porcu, O. M. (2013). Elaboração de biscoitos integral utilizando óleo e farinha da polpa de abacate. $B$ CEPPA, 31(2), 215-226.

Deamici, K. M., Oliveira, L. C., Rosa, G. S., Zavareze, E. R., \& Oliveira, E. G. (2018). Development of cookies from agroindutrial by-products. Revista Brasileira de Fruticultura, 40(2), 1-7.

Dilucia, F., Lacivita, V., Conte, A., \& Del Nobile, M. A. (2020). Sustainable use of fruit and vegetable by-products to enhance food packaging performance. Foods, 9(1), 857-876.

Dutcosky, S. D. (2011). Análise sensorial de alimentos: Champagnat.

Farias, N. S., Cavalcanti, M. T., Eller, S. C., Feitosa, V. A., \& Florentino, E. R. (2011). Elaboração de biscoitos tipo cookie enriquecido com macambira (Bromélia laciniosa). Revista Verde, 6(4), 50 -57.

Fasolin, L. H., Almeida, G. C., Castanho, P. S., \& Netto-Oliveira, E. R. (2007). Biscoitos produzidos com farinha de banana: avaliações química, física e sensorial. Ciência e Tecnologia de Alimentos, 27(3), 524-529.

Fernandes, A. F., Pereira, J., Germani, R., \& Oiano-Neto, J. (2008). Efeito da substituição parcial da farinha de trigo por farinha de casca de batata (Solanum tuberosum Lineu). Ciência e Tecnologia de Alimentos, 28, 56-65.

Fidelis, M., Moura, C., Junior, T. K, Pap, N., Marttila, P., Makinen, S., Putnik, P., Kovacevik, D. B., Yang, B., \& Granato, D. (2019). Fruit seeds as sources of bioactive compounds: Sustainable production of high value-added ingredients from by-products within circular economy. Molecules, 24(1), 3854-3908.

Foyet, M., \& Tchango-Tchango, J. (1994). Transformation de la goyave et de la grenadille extraction de pulpe, formulation et conservation de nectars. Fruits, $49,61-70$.

Horwitz, W. (1980). Official methods of analysis of AOAC International (13th ed): AOAC International.

Jalali, M., Karamizadeh, M., Ferns, G. A., Zare, M., Moosavian, S. P., \& Akbarzadeh, M. (2020). The effects of cashew nut intake on lipid profile and blood pressure: A systematic review and meta-analysis of randomized controlled trials. Complementary Therapies in Medicine, 50(1), 102387.

Kooper, A. C., Saraiva, A. K., Ribani, R. H., \& Lorenzi, G. A. (2009). Technological use of bocaiuva. Alimentos e Nutrição, 20, 463-469.

Lima, S. K. R., Nóbrega, M. M. G. P., Carneiro, R. M., Silva, R. A., Medeiros, S. R. A., \& Muratori, M. C. S. (2021). Formulation of food bars based on the co-product of cashew penducle (Anacardium occidentale L) and whey. Research, Society and Development, 10(1), e7010111213.

Lousada Junior, J. E., Costa, J. M. C., Neiva, J. N. M., \& Rodriguez, N. M. (2006). Caracterização físico-química de subprodutos obtidos do processamento de frutas tropicais visando seu aproveitamento na alimentação animal. Revista Ciência Agronômica, 37(1), 70-76.

Lutz. I. A. (1985). Normas analíticas do Instituto Adolfo Lutz: métodos químicos e físicos para análises de alimentos: Instituto Adolfo Lutz.

Marín, F. R., Frutos, M. J., Pérez-Alvarez, J. Á., Martí́nez-Sánchez, F., \& Del Río, J. A. (2002). Flavonoids as nutraceuticals: structural related antioxidant properties and their role an ascorbic acid preservation. Studies in Natural Products Chemistry, 26, 741-778.

Matias, M. F. O., Oliveira, E. L., Margalhães, M. M. A., \& Gertrudes, E. (2005). Use of fibers obtained from the cashew (Anacardium ocidentale L) and guava (Psidium guayava) fruits for enrichment of food products. Brazilian Archives of Biology and Technology, 8, 143-150.

Medeiros, J. S., Santos, L. S., Ferreira, S. V., \& Machado, A. R. (2020). Development of biscuits from the residue from the extraction of cashew juice from the cerrado of Goiás. Research, Society and Development, 9(7), e39973082.

Meilgaard, M. C., Civille, G. V., \& Carr, B. T. (2016). Sensory Evaluation Techniques. Boca Raton: CRC Press, Taylor \& Francis Group.

Menezes, E. W., Tadini, C, C., Tribess, T. B., Zuleta, A., Binagui, J., Pak, N., Vera, G., Dan, M. C., Bertolini, A. C., Cordenunsi, B. R., \& Lajolo, F. M. (2011). Chemical composition and nutritional value of unripe banana flour (Musa acuminata, var. nanicão). Plants Food for Human Nutrition, 66 (3), 231237.

Ministério da Saúde/ANVISA. Agência Nacional de Vigilância Sanitária. Portaria n 33, de 13 de janeiro de 1998. Aprova o regulamento que adota a Ingestão Diária Recomendada (IDR) para vitaminas, minerais e proteínas. Diário Oficial da União; Poder Executivo.

Ministério da Saúde/ANVISA. Agência Nacional de Vigilância Sanitária. Resolução RDC no 263, de 22 de setembro de 2005 - Regulamento técnico para produtos de cereais, amidos, farinhas e farelos. Diário Oficial da União; Poder Executivo. SVS/MS -Ministério da Saúde. Secretaria de Vigilância Sanitária. 
Mirabella, N., Castellani, V., \& Sala, S. (2014). Current options for the valorization of food manufacturing waste: a review. Journal of Cleaner Production, $65,28-41$.

Müller, Mattea., Canfora, E. E., \& Blaak, E. E. (2018). Gastrointestinal transit time, glucose homeostasis and metabolic health: Modulation by dietary fibers. Nutrients, 10(3), 275.

Nogueira, T. B. B., Silva, T. P. M., Luiz, D. A., Andrade, C. J., Andrade, L. M., Ferreira, M. S. L., \& Fai, A. E. C. (2020). Fruits and vegetables-processing waste: A case study in two markets at Rio de Janeiro, RJ, Brazil. Environmental Science and Pollution Research, 1-11.

Pereira, A. S., Shitsuka, D. M., Parreira, F. J., \& Shitsuka, R. (2018). Metodologia da pesquisa científica. UFSM. https://repositorio.ufsm.br/bitstream/handle/1/15824/Lic_Computacao_Metodologia-Pesquisa-Cientifica.pdf?sequence=1.

Pinto, C. F., Malta, H. L., \& Cruz, R. S. (2011). Desenvolvimento e avaliação de biscoitos enriquecido com fibra de caju. UEFS, 1, 535-538.

Rico, R., Bulló, M., \& Salvadó, J. S. (2016). Nutritional composition of raw fresh cashew (Anacardium occidentale L.) kernels from different origin. Food Science \& Nutrition, 4(2), 329-338.

Ribeiro, R. D., \& Finzer, J. D. (2010). Desenvolvimento de biscoito tipo cookie com aproveitamento de farinha de sabugo de milho e casca de banana. $F A Z U$ em Revista, 7, 120-124.

Rosa, M. Y. O., \& Lobato, F. H. S. (2020). Cashew burger: Elaboration and sensorial analysis of hamburger based on cashew (Anacardium occidentale L). Research, Society and Development, 9(8), e615985958.

Salehi, B., Özgüven, M. G., Kirkin, C., Özçelik, B., Braga, M. F. B. M., Carneiro, J. N. P., Bezerra, C. F., Silva, T. G., Coutinho, H. D. M., Amina, B., Armstrong, L., Selamoglu, Z., Sevindik, M., Yousaf, Z., Rad, J. S., Muddathir, A. M., Devkota, H. P., Martorell, M., Jugran, A. K., Martins, N., \& Cho, W. C. (2019). Anacardium plants: chemical, nutritional composition and biotechnological applications. Biomolecules, 9, 465-499.

Salgado, J. M., Danieli, F., Reginato-Darc'e, M. A. B., Frias, A., \& Mansi, D. M. (2008). O óleo de abacate (Persea americana Mill) como matéria-prima para indústria alimentícia. Ciência e Tecnologia de Alimentos, 28, 20-26.

Santos, R. P., Santiago, A. A. X., Gadelha, C. A. A., Cajazeiras, J. B., Cavada, B. S., Martins, J. L., Oliveira, T. M., Bezerra, G. A., Rinaldo, O. S., \& Freire, V. N. (2007). Production and characterization of the cashew (Anacardium ocidentale L) penducle bagasse ashes. Journal of Food Engineering, $79,1432-1437$.

Schieber, A., Stintzing, F. C., \& Carle, R. (2001). Byproducts of plant food processing as a source of functional compounds: recent developments. Trends Food Science Technology, 12(11), 401-413.

Schweiggert, R. M., Vargas, E., Conrad, J., Hempel, J., Gras, C. C., Ziegler, J. U., \& Carle, R. (2016). Carotenoids, carotenoid esters, and anthocyanins of yellow-, orange-, and red-peeled cashew apples (Anacardium occidentale L.). Food Chemistry, 200, 274-282.

Sgarbieri, V. C. (1987). Alimentação e nutrição: fator de saúde e desenvolvimento. Ed. Almed.

Silva, L. M. R., Figueiredo, E. A. T. D. E., Ricardo, N. M. P. S., Vieira, I. G. P., Figueiredo, R. W. D. E., \& Brasil, I. M. (2014). Quantification of bioactive compounds in pulps and by-products of tropical fruits from Brazil. Food Chemistry, 143, 398-404.

Soares, R. M., Vieira, E. L., Francisco, A. S., \& Roberta, M. (2000). Fibras alimentares: histórico, classificação e efeitos fisiológicos. In: Simpósio SulBrasileiro De Alimentação E Nutrição: História E Arte, 237-241.

Sousa, M. S. B., Vieira, L. M., Silva, A. O., Mancini-Filho, J., \& Lima, A. (2011). Nutritional characterization and antioxidant compounds in pulp residues of tropical fruits. Ciência e Agrotecnologia, 35(3), 554-559.

Souza, R. L. A., Oliveira, L. S. C., Silva, F. L. H., \& Amorim, B. C. (2010). Caracterização da poligalacturonase produzida por fermentação semi-sólida utilizando-se resíduo de maracujá como substrato. Revista Brasileira de Engenharia Agrícola e Ambiental, 14(9), 987-992.

Oliveira, N. N., Mothé, C. G., Mothé, M. G., \& Oliveira, L. G. (2020). Cashew nut and cashew apple: A scientific and technological monitoring worldwide review. Journal of Food Science and Technology, 57(1), 12-21.

Uchoa, A. M. A., Costa, J. M. C., Maia, G. A., Meira, T. R., Sousa, P. H. M., \& Brasil, I. M. (2009). Formulation and physicochemical and sensorial evaluation of biscuit-type cookies supplemented with fruit powders. Plants Food for Human Nutrition, 64(2), 153-159.

Wu, X., Beecher, G. R., Holden, J. M., Haytowitz, D. B., Gebhardt, S. E., \& Prior, R. L. (2004). Lipophilic and hydrophilic antioxidant capacities of common foods in the United States. Journal of Agricultural and Food Chemistry, 52(12), 4026-4037.

Yang, J., Paulino, R., Janke-Stechonsky, S., \& Abawi, F. (2007). Free-radical-scavenging activity and total phenols of noni (Morinda Citrifolia L.) juice and powder in processing and storage. Food Chemistry, 102, 302-308. 